\title{
JENIS-JENIS DAN POTENSI JAMUR MAKROSKOPIS YANG TERDAPAT DI PT PERKEBUNAN HASIL MUSI LESTARI DAN PT DJUANDA SAWIT KABUPATEN MUSI RAWAS
}

Linna Fitriani ${ }^{*}$, Yuni Krisnawati ${ }^{2}$, Msy Olivia Rega Anorda 3 , Ketri Lanjarini ${ }^{4}$

1,2,3,4 STKIP PGRI Lubuklinggau, Jl. Mayor Toha Kel. Air Kuti, Lubuklinggau 31626, Indonesia

*Corresponding author, e-mail: linna.fitriani@yahoo.com

\section{ABSTRACT}

This study aimed to determine the types and potential of macroscopic fungi in oil palm plantations at PT Musi Lestari Plantation and PT Djuanda Sawit Plantation in Musi Rawas Regency. This research is descriptive qualitative research. Sampling is done by using a purposive sampling method with roaming techniques. The macroscopic fungal species found in the field were made into wet herbarium and identified. The research data were analyzed descriptively. The results of the study obtained 35 species. 35 species of macroscopic fungi including Clitoybe dealbata, Clitoybe decembris, Collybia sp., Collybia chirata, Collybia confluens, Collybia butyracea, Marasminus sp., Boletus sp., Hipholoma marginatum, Pleurotus varreatus, Pleurotus ostreatus, Crepurususus spidus, Crepurususus sp. rameus, Lactarius sp., Volvariella volvaceae, rhacodes Lepiota, Amanita fulva, Amanita virosa, Parasola lactea, Auricularia polytricha, Spongipelis sp., Grivola sp., Grivola sp., Grivola sp., Fvom phomentarius, Ganoderma sp. , Panus sp., Coltricia sp., Coltricia perennes, Pycnoporus cinnabarinus, Tulostoma sp., Lycoperdon gemmatum, Peziza repanda, and Peziza vesiculosa. The conclusions of 35 species were found, belonging to 6 orders, 16 families, and 24 genera. 8 species or $23 \%$ macroscopic fungi can be consumed.

Keywords: Macroscopic Mushrooms, Oil Palm Plantation, Musi Rawas

\section{PENDAHULUAN}

Indonesia merupakan salah satu negara beriklim tropis yang memiliki kelembapan tinggi sehingga memungkinkan untuk tumbuhnya berbagai tanaman dan mikroorganisme dengan baik. Salah satu mikroorganisme yang dapat tumbuh dengan baik di Indonesia adalah jamur (Arifin, 2006). Jamur atau cendawan adalah organisme heterotrofik. Mereka memerlukan senyawa organik untuk nutrisinya (Gandjar, 2006). Selain itu Darwis, dkk (2011) menyatakan bahwa jamur merupakan organisme eukariotik, berspora, tidak berklorofil, bereproduksi secara seksual dan aseksual, jamur berdasarkan ukuran tubuhnya ada yang makroskopis yaitu jamur yang berukuran besar, sehingga dapat dilihat dengan mata telanjang dan ada juga jamur yang mikroskopis yaitu jamur yang berukuran kecil dan hanya dapat dilihat dengan menggunakan alat bantu mikroskop. Jamur makroskopis memiliki struktur umum yang terdiri atas bagian tubuh yaitu bilah, tudung, tangkai, cincin, dan volva. Namun ada juga jamur makroskopis yang tidak memiliki salah satu bagian seperti tidak bercincin (Alexopolus, dkk., 1996).

Jamur mempunyai peranan penting dalam ekosistem. Jamur merupakan dekomposer (pengurai) dan menjadi penyeimbang keanekaragaman jenis hutan. Jamur mampu menguraikan bahan organik seperti selulosa, hemiselulosa, lignin, 
protein, dan senyawa pati dengan bantuan enzim. Jamur menguraikan bahan organik menjadi senyawa yang diserap dan digunakan untuk pertumbuhan dan perkembangan (Hasanuddin, 2014). Jamur secara luas dihargai di seluruh dunia untuk nilai gizi dan pengobatan. Mereka memiliki rendah lemak, protein tinggi dan vitamin. Jamur mengandung beberapa mineral dan elemen, serta sejumlah serat makanan (Badalyan, 2012).

Secara alamiah jamur banyak dijumpai pada tempat dengan kondisi lingkungan yang lembab. Jamur dapat ditemukan pada batang tumbuhan, di halaman rumah setelah hujan, pada sisa makanan yang sudah basi dan di tempat-tempat basah atau tempat yang kaya akan zat organik (Darwis, dkk., 2011). Jamur biasanya tumbuh pada kondisi lingkungan yang teduh dan tingkat kelembapan yang cukup tinggi, arus angin dan pencahayaan. Beberapa faktor lainnya adalah kebutuhan sinar matahari tidak langsung, pada kondisi ini jamur dapat tumbuh dengan cepat, suhu dan sirkulasi udara yang sejuk, dan kondisi lingkungan dataran rendah sangat cocok untuk kehidupan jamur makroskopis Hidayati, dkk, 2015). Hal ini sesuai dengan hasil observasi pada 14 Mei 2017 di PT Perkebunan Hasil Musi Lestari (PHML) Kecamatan BTS ULU Kabupaten Musi Rawas dan Perkebunan PT Djuanda Sawit, Kecamatan Muara Kelingi, Kabupaten Musi Rawas bahwa terdapat beberapa jenis jamur makroskopis yang hidup dan tumbuh di perkebunan kelapa sawit. Jamur tersebut antara lain Volvariella volvacea, Sclorederma aurantium dan Auricularia polytricha. Hal ini dikarenakan lingkungan yang memadai untuk pertumbuhan dan perkembangan jamur. Perkebunan kelapa sawit tidak hanya terdapat banyak pohon kelapa sawit melainkan juga limbah pengolahan kelapa sawit seperti tandan kosong kelapa sawit serta limbah dari perkebunannya sendiri seperti serasah, pelepah, serta pohon yang sudah tumbang.

Berdasarkan hasil wawancara kepada masyarakat di sekitar perkebunan, masyarakat sering mengkonsumsi beberapa jamur. Selain itu diketahui bahwa penelitian mengenai jenis jamur makroskopis yang terdapat di dua PT perkebunan kelapa sawit tersebut belum pernah dilakukan. Berdasarkan hal yang telah diuraikan serta peranan jamur yang sangat penting bagi kehidupan, maka dilakukanlah penelitian dengan tujuan untuk menginventarisasi jamur dan potensi jamur makroskopis yang terdapat di PT Djuanda Sawit Lestari di Kecamatan Muara Kelingi Kabupaten Musi Rawas dan PT Perkebunan Hasil Musi Lestari (PHML) Kecamatan BTS ULU Kabupaten Musi Rawas.

\section{METODE}

Penelitian ini merupakan penelitian eksplorasi dengan menentukan lokasi penelitian secara purposive areal sampling (Usman, 2006) yaitu teknik pengambilan sampel didasarkan pada tujuan tertentu. Penelitian dilaksanakan pada bulan Juni sampai September 2017. Sampel jenis-jenis jamur makroskopis yang ditemukan di lapangan dibungkus dan dimasukkan ke dalam amplop coklat untuk dibuat herbarium basah. Pembuatan herbarium basah menggunakan alkohol 70\% untuk merendam spesimen di dalam toples (Darwis, dkk., 2009). Sebelum sampel diambil dilakukan pemotretan. Identifikasi jenis jamur makroskopis menggunakan buku acuan dari Mushrooms \& Toadstools (Wilkinson, 1982) dan Introductory Mycology (Alexopoulus, 1962). Untuk melengkapi data sampel penelitian, maka dilakukan pengamatan faktor abiotik lingkungan, antara lain: $\mathrm{pH}$, suhu, dan kelembapan udara. Teknik wawancara juga digunakan untuk mengetahui jenis jamur yang dapat dan tidak dapat dikonsumsi. Responden adalah masyarakat sekitar yang mengkonsumsi jamur serta penjual jamur. 


\section{HASIL DAN PEMBAHASAN}

Hasil penelitian jamur makroskopis di perkebunan kelapa sawit di PT Djuanda Sawit Kecamatan Muara Kelingi Kabupaten Musi Rawas pada bulan Juni sampai Juli 2017, didapatkan 12 spesies jamur makroskopis yang termasuk ke dalam 3 ordo, 6 family, dan 8 genus. Tiga ordo tersebut antara lain Agaricales, Lycoperdales dan Pezizales; 6 Family (Agaricaceaae, Tricholomataceae, Amanitaceae, Psthyrellceae, Lycoperdon, Pezizaceae); 8 genus (Volvariella, Collybia, Lepiota, Pleurotus, Amanita, Parasola, Lycoperdon, dan Peziza); dan 12 spesies (Volvariella volvaceae, Pleurotus ostreatus, Collybia confluens, Amanieta vulva, Lepiota rhacodes, Amanita virosa, Collybia butyracea, Parasola lactea, Lycoperdon praense, Lycoperdon gemmatum, Peziza repanda dan Peziza vesiculosa.

Tabel 1. Jenis-jenis Jamur dan PT Perkebunan Hasil Musi Lestari Kecamatan BTS ULU dan di PT Djuanda Sawit Kecamatan Muara Kelingi Kabupaten Musi Rawas

\begin{tabular}{|c|c|c|c|c|}
\hline No. & Ordo & Family & Genus & Spesies \\
\hline \multirow[t]{13}{*}{1} & Agaricales & Tricholomataceae & Clitoybe & $\begin{array}{l}\text { Clitoybe dealbata, } \\
\text { Clitoybe decembris }\end{array}$ \\
\hline & & & Collybia & $\begin{array}{l}\text { Collybia sp, } \\
\text { Chollybia chirata } \\
\text { Collybia confluens, } \\
\text { Collybia butyacea }\end{array}$ \\
\hline & & & Marasmius & Marasmius sp \\
\hline & & Boletaceae & Boletus & Boletus sp \\
\hline & & Hygrophoraceae & Hypholoma & Hipholoma marginatum \\
\hline & & Pleurotaceae & Pleurotus & Pleurotus pulmonarius \\
\hline & & & & Pleurotus ostreatus \\
\hline & & & Crepidotus & $\begin{array}{l}\text { Crepidotus fusisporus var. } \\
\text { Rameus }\end{array}$ \\
\hline & & Russulaceae & Lactarius & Lactarius sp \\
\hline & & Agaricaceaae & Volvariella & Volvariella volvaceae \\
\hline & & & Lepiota & Lepiota rhacodes \\
\hline & & Amanitaceae & Amanita & $\begin{array}{l}\text { Amanieta fulva } \\
\text { Amamnita virosa }\end{array}$ \\
\hline & & Psthyrellceae & Parasola & Parasola lactea \\
\hline 2 & Auriculariales & Auriculariaceae & Auricularia & Auricularia polytricha \\
\hline 3 & Aphylloporales & Schizophylaceae & Auriculariopsis & Schyzophylim commune \\
\hline \multirow[t]{7}{*}{4} & Polyporales & Hydnaceae & Spongipelis & Spongipelis sp \\
\hline & & Meripilaceae & Grivola & Grivola sp \\
\hline & & Polyporaceae & Fomes & $\begin{array}{l}\text { Fomes fomentarius, } \\
\text { Fomes sp1 } \\
\text { Fomes sp2 }\end{array}$ \\
\hline & & & Lenzites & Lenzites betulina \\
\hline & & & Panus & Panus sp \\
\hline & & & Polyporus & $\begin{array}{l}\text { Polyporus sp1, } \\
\text { Polyporus sp2 }\end{array}$ \\
\hline & & & Pycnoporus & Pycnoporus cinnabarinus \\
\hline \multirow[t]{3}{*}{5} & Licoperdales & Lycoperdaceae & Tulostoma & Tulostoma sp \\
\hline & & Lycoperdon & Lycoperdon & Lycoperdon pratense \\
\hline & & & & Lycoperdon gemmatum \\
\hline 6 & Pezizales & Pezizaceae & Peziza & $\begin{array}{l}\text { Peziza repanda } \\
\text { Peziza vesiculosa }\end{array}$ \\
\hline
\end{tabular}


Penelitian pada Agustus sampai September 2017 di PT Perkebunan Hasil Musi Lestari (PHML) Kecamatan BTS ULU Kabupaten Musi Rawas ditemukan 24 spesies dari 5 ordo, 11 famili, 19 genus. 5 ordo tersebut antara lain Agaricales, Auriculariales, Aphylloporales, Lycoperdales, Polyporales; 11 Famili (Auriculariaceae, Boletaceae, Hydnaceae, Hygrophoraceae, Pleurotaceae, Lycoperdaceae, Meripilaceae, Schizophylaceae, Tricholomataceae, Polyporaceae); 18 Genus (Auricularia, Auriculariopsis, Boletus, Clitoybe, Collybia, Crepidotus, Fomes, Ganoderma, Grivola, Hypholoma, Spongipelis, Tulostoma, Panus, Pleurotus, Polyporus, Lactarius, Lenzites), dan memiliki 24 Spesies (Auricularia polytricha, Boletus sp., Clitoybe dealbata, Clitoybe decembris, Collybia sp., Collybia chirata, Coltricia sp., Coltricia perennes, Crepidotus fusisporus var. rameus, Fomes sp., Ganoderma sp.1, Ganoderma sp.2, Grivola sp., Hipholoma marginatum, Lactarius sp., Lenzites sp., Lenzites betulina, Marasmius sp., Panus sp. Jika hasil penelitian jamur di dua perkebunan tersebut digabungkan, maka jumlah spesies yang diperoleh sebanyak 35 spesies dari 6 ordo, 16 family, dan 24 genus. Jenis-jenis jamur makroskopis yang terdapat di PT Perkebunan Hasil Musi Lestari (PHML) dan PT Djuanda di Kabupaten Musi Rawas dapat dilihat pada tabel 1.

Tabel 2. Potensi Jamur Makroskopis yang Ditemukan di PT Djuanda Sawit dan PT Perkebunan Hasil Musi Lestari, Kecamatan BTS ULU Kabupaten Musi Rawas

\begin{tabular}{|c|c|c|}
\hline No. & Spesies & Potensi \\
\hline 1. & Clitoybe dealbata & Non Pangan \\
\hline 2. & Clitoybe decembris & Non Pangan \\
\hline 3. & Collybia sp. & Non Pangan \\
\hline 4. & Chollybia chirata & Non Pangan \\
\hline 5. & Collybia confluens & Non Pangan \\
\hline 6. & Collybia butyracea & Non Pangan \\
\hline 7. & Marasmius sp & Non Pangan \\
\hline 8. & Boletus sp. & Non Pangan \\
\hline 9. & Hipholoma marginatum & Non Pangan \\
\hline 10 & Pleurotus pulmonarius & Pangan \\
\hline 11. & Pleurotus ostreatus & Pangan \\
\hline 12. & Crepidotus fusisporus var. rameus & Non Pangan \\
\hline 13. & Lactarius sp. & Non Pangan \\
\hline 14. & Volvariella volvaceae & Pangan \\
\hline 15. & Lepiota rhacodes & Non Pangan \\
\hline 16. & Amanieta fulva & Non Pangan \\
\hline 17. & Amanita virosa & Non Pangan \\
\hline 18. & Parasola lacteal & Non Pangan \\
\hline 19. & Auricularia polytricha & Non Pangan \\
\hline 20. & Schyzophylim commune & Pangan \\
\hline 21 & Spongipelis sp. & Non Pangan \\
\hline 22 & Grivola sp. & Pangan \\
\hline 23 & Fomes Fomentarius & Non Pangan \\
\hline 24 & Ganoderma sp.1 & Obat \\
\hline 25 & Ganoderma sp 2 & Obat \\
\hline 26 & Lenzites betulina & Non Pangan \\
\hline 27 & Panus sp & Non Pangan \\
\hline 28 & Coltricia sp & Pangan \\
\hline 29 & Coltricia perennes & Non Pangan \\
\hline 30 & Pycnoporus cinnabarinus & Non Pangan \\
\hline 31 & Tulostoma sp & Pangan \\
\hline 32 & Lycoperdon pretense & Non Pangan \\
\hline 33 & Lycoperdon gemmatum & Non Pangan \\
\hline 34 & Peziza repanda & Pangan \\
\hline 35 & Peziza vesiculosa & Non Pangan \\
\hline
\end{tabular}


Pemanfaatan jamur baik sebagai bahan pangan, obat-obatan dan bahan kosmetik telah berlangsung sejak lama. Menurut sejarah Romawi atau Raja Pharoahs pada masa kerajaan Mesir, jamur menjadi makanan raja, para bangsawan seta pasukan kerajaan yang dipercayai memperpanjang umur, meningkatkan imunitas (Jahan, dkk, 2010). Selain itu, menurut Parjimo (2007), beberapa jenis jamur telah banyak dimanfaatkan oleh manusia sebagai bahan makanan dan sumber bahan obatobatan tradisonal. Menurut Chew, dkk., (2008) jamur yang berwarna sangat mencolok, tidak terdapat gigitan dari organisme lain dan menimbulkan bau busuk biasanya mengandung senyawa sulfida yang menimbulkan bau busuk seperti bau telur busuk $\left(\mathrm{NH}_{3}\right)$ atau senyawa sianida. Biasanya jamur dengan ciri-ciri tersebut mengandung racun dan tidak dimanfaatkan oleh masyarakat sekitar. Dari 35 jenis jamur yang teridentifikasi hanya 8 jenis jamur atau 23\% saja yang dapat dikonsumsi. Potensi jamur makroskopis yang ditemukan di PT Djuanda Sawit dan PT Perkebunan Hasil Musi Lestari (PHML) dapat dilihat pada tabel 2.

Selain tempat hidup yang memadai untuk pertumbuhan jamur, jamur yang ditemukan dalam penelitian ini juga dipengaruhi oleh faktor lingkungan sehingga jamur ini dapat berkembang pada suhu tanah dan kelembapan tanah yang rendah dan tempat yang cocok. Sama halnya penelitian yang dilakukan oleh Proborini (2012) yang menyatakan bahwa pertumbuhan badan buah dan penebaran jamur-jamur dari kelas Basidiomycetes sangat dipengaruhi oleh faktor lingkungan, antara lain faktor suhu, kelembapan Faktor kelembapan tanah yang sangat cocok dalam mempengaruhi pertumbuhan jamur adalah dengan kelembapan antara $80-90 \%$ dan kisaran suhu tanah $18-28^{\circ} \mathrm{C}$ yang paling susah untuk pertumbuhan jamur. Dengan kata lain, faktor abiotik di kedua PT perkebunan kelapa sawit tersebut cocok untuk keberlangsungan hidup jamur. Data Faktor Abiotik di PT Djuanda Sawit dan PT Perkebunan Hasil Musi Lestari (PHML) Kecamatan BTS ULU Kabupaten Musi Rawas dapat dilihat pada Tabel 3 .

Tabel 3. Data Faktor Abiotik di PT Djuanda Sawit dan PT Perkebunan Hasil Musi Lestari, Kecamatan BTS ULU Kabupaten Musi Rawas

\begin{tabular}{llll}
\hline No. & Faktor Abiotik & \multicolumn{1}{c}{ PT Djuanda Sawit } & \multicolumn{1}{c}{$\begin{array}{c}\text { Nilai } \\
\text { PT Perkebunan Hasil Musi } \\
\text { Lestari (PHML) }\end{array}$} \\
1. & $\mathrm{pH}$ & $5-6$ & $5,2-6,4$ \\
2. & Suhu udara & $23,9^{\circ} \mathrm{C}-26,3^{\circ} \mathrm{C}$ & $25,5^{\circ} \mathrm{C}-29^{\circ} \mathrm{C}$ \\
3. & Kelembapan udara & $75-85 \%$ & $85-92 \%$ \\
\hline
\end{tabular}

Jamur-jamur yang ditemukan di PT Djuanda Sawit dan PT Perkebunan Hasil Musi Lestari (PHML) Kecamatan BTS ULU Kabupaten Musi Rawas sebagian besar ditemukan hidup di tandan kosong kelapa sawit sisa produksi kelapa sawit, pelepah yang telah jatuh dan lapuk, pohon kelapa sawit yang masih hidup maupun yang sudah tumbang, serta serasah daun dan tanah. Dari hasil penelitian, jenis jamur yang paling banyak ditemukan yaitu jamur dari Ordo Agaricales, yaitu sebanyak 18 jenis jamur. Jamur ini lebih mudah ditemukan dari jamur lain karena tubuh buah jauh lebih besar dan mudah tumbuh pada limbah tandan kosong kelapa sawit. Kawasan ditemukan jenis jamur ini adalah tumpukan limbah tandan kosong kelapa sawit yang mulai lapuk dan ternaungi pohon kelapa sawit. Menurut Tjitrosoepomo (2011) jamur makroskopis dari Ordo Agaricales memiliki tubuh buah berbentuk payung dengan letak tangkai yang sentral. Pada waktu muda, tubuh buah itu diselubungi oleh suatu selaput. Jika tubuh membesar, tinggalah selaput pada pangkal tangkai buah yang 
menjadikan jamur jenis ini mudah dikenali.

Ordo Auriculariales hanya ditemukan satu spesies saja yaitu Auricularia polytricha. Menurut Utoyo (2010) Auricularia polytricha (jamur kuping hitam, black jelly, arage kikurage) berukuran kecil daripada jamur kuping merah. Karena itu jamur ini memiliki produktivitas yang lebih rendah. Jamur ini berbentuk seperti cendawan pipih dengan bagian tepi melengkung ke atas. Tubuh buahnya kecil, tebal dan berwarna coklat tua kehitaman. Jamur ini lebih banyak dipasarkan dalam bentuk kering.

Menurut Hiola (2011) Bangsa Aphylloporales banyak tumbuh di pohon-pohon yang tumbang dan sudah lapuk, dengan kondisi optimum suhu yang berkisar 10$15^{\circ} \mathrm{C}$, dan kelembapan sekitar $90 \%$. Hal ini sangatlah wajar jika hanya satu spesies saja yang ditemukan yaitu Schyzophylim commune. Sebagian besar jamur dari bangsa Aphylloporales yang ditemukan bersifat parasit, yaitu tumbuh pada batang pohon, sehingga dapat menyebabkan kerusakan pada pohon atau pohon menjadi mati (Proborini, 2012).

Ordo Polyporales terdiri atas 3 famili dan 10 spesies. Menurut Arora (1986) Polyporaceae merupakan satu diantara beberapa famili terbesar yang memiliki banyak warna, bentuk dan ukuran. Famili Polyporaceae memiliki ciri umum berbentuk braket atau kipas dengan permukaan himenium berupa lubang-lubang kecil yang disebut pores atau modifikasinya. Tubuh buahnya berkayu, tebal dan kasar. Polyporales kebanyakan tumbuh pada kayu.

Ordo Lycoperdales memiliki tubuh buah yang bulat atau bulat-lonjong. Tubuh buahnya menyerupai biji jagung. Ada juga yang tubuh buahnya kurus berdinding tipis, yang pada saat tua isi dalamya atau sporanya yang di dalam akan terbebas melalui lubang kecil di bagian atas tubuh buah. Ada jenis jamur pada ordo Lycoperdales yang ketika masih muda, dagingnya berwarna putih dapat dimakan dan sangat lezat (Wilkinson, 1982).

Ordo Pezizales merupakan salah satu ordo dari ascomycetes yang paling dikenal. Tubuh buah jamur pezizales berbentuk mangkok. Jamur dalam ordo ini memiliki beberapa bentuk, fitur ini cukup disamarkan sebagai bagian tubuh buah yang lebih besar. Morchella adalah genus yang paling penting diantara kelompok ascomiycetes, walaupun secara dasar sangat berbeda, mereka memiliki spora yang serupa dan digolongkan bersama berdasarkan basis ini (Wilkinson, 1982).

Hanya ditemukan 2 jenis jamur dari Ordo Pezizales, yaitu Peziza repanda dan Peziza vesicula. Hal itu disebabkan karena pada umumnya jamur dari ordo ascomycetes adalah jamur mikroskopis, dan hanya sebagian kecil dari ordo ini yang merupakan jamur makroskopis. Seperti contohnya Pezizales. Jamur jenis Peziza repanda merupakan jamur yang paling sering ditemukan pada blok-blok penelitian. Hal ini disebabkan limbah tandan kosong kelapa sawit di PT Djuanda sawit memiliki faktor abiotik pH 5,2-6,6, suhu $24,5^{\circ} \mathrm{C}-29^{\circ} \mathrm{C}$ dan kelembapan $85 \%-92 \%$ yang sesuai untuk pertumbuhan jamur sesuai pendapat Hasanuddin (2014), jamur dapat tumbuh baik di daerah beriklim dingin maupun panas dengan suhu optimum antara $20-28^{\circ} \mathrm{C}$. Jamur akan tumbuh dan berkembang dengan baik pada suhu $16^{\circ} \mathrm{C}$, kelembapan $97 \%$ serta $\mathrm{pH}$ optimum antara 5-7,5.

Dari berbagai macam jamur yang telah ditemukan dan diidentifikasi jenisnya, ada jenis jamur yang bisa dikonsumsi maupun jenis yang beracun. Jamur yang bisa dikonsumsi sebanyak 23\% dari 35 jenis jamur yang bisa ditemukan. Jamur yang dapat dikonsumsi mempunyai kandungan garam mineral yang tinggi dari pada yang dikandung dalam daging sapi atau daging domba. Jumlah garam mineral yang 
dikandung jamur bisa mencapai hampir 2 kali lipat jumlah garam mineral dalam sayur lainnya. Jumlah protein yang dikandung jamur mencapai 2 kali lipat dari protein yang terdapat dalam asparagus, kol dan kentang, 4 kali dari tomat, wortel dan 6 kali lipat dari jeruk. Selain itu juga mengandung garam-garam besi, tembaga, kalium dan kapur. Jamur juga kaya akan vitamin B dan vitamin D yang berasal dari substitusi sinar matahari. Jamur beracun biasanya berwarna sangat mencolok, tidak terdapat gigitan dari organisme lain dan biasanya berbau busuk karena mengandung senyawa sulfida (Darwis dkk, 2011). Beberapa jamur dari hasil penelitian yang dapat dikonsumsi menurut warga dan referensi yang ada antara lain Volvariella volvacea, Pleurotus ostreatus, dan Peziza repanda.

Menurut Anggraini, dkk (2015) faktor lingkungan pada setiap spesies jamur berbeda-beda. Pengukuran suhu tanah menunjukan kisaran $27^{\circ} \mathrm{C}-38^{\circ} \mathrm{C}$. Hasil pengukuran kelembapantanah menunjukkan kisaran 70\%-80\%. Seperti yang telah peneliti ukur pada jamur Schyzophylum commune memiliki suhu tanah berkisar $23,9^{\circ} \mathrm{C}-26,3^{\circ} \mathrm{C}$ dengan kelembapantanah $75-82 \%$ sedangkan jamur Lenzites sp tumbuh dengan suhu tanah $23,9^{\circ} \mathrm{C}$ dan $80 \%$ kelembapan tanah. Hal ini sesuai dengan pendapat dari Hasanuddin (2014) bahwa jamur dapat tumbuh baik di daerah beriklim dingin maupun panas dengan suhu tanah optimum antara $20^{\circ} \mathrm{C}-28^{\circ} \mathrm{C}$.

Kedua perkebunan kelapa sawit merupakan daerah yang baik untuk pertumbuhan jamur. Hal ini disebabkan oleh faktor lingkungan yang sangat mendukung yaitu $\mathrm{pH}$ 5,2-6,6; suhu $24,5^{\circ} \mathrm{C}-29^{\circ} \mathrm{C}$ dan kelembapan $85 \%-92 \%$. Jamur sangat cocok hidup di daerah yang teduh, sejuk dan lembab seperti yang terdapat pada limbah tandan kosong kelapa sawit, pelepah lapuk, serasah daun dan tanah, serta pohon kelapa sawit yang masih hidup maupun yang sudah mati. Hal ini sesuai dengan pendapat Hasanuddin (2014), jamur dapat tumbuh baik di daerah beriklim dingin maupun panas dengan suhu optimum antara $20-28^{\circ} \mathrm{C}$. Beberapa faktor lainnya adalah kebutuhan sinar matahari tidak langsung, kelembapan udara, suhu dan sirkulasi udara. Jamur akan tumbuh dan berkembang dengan baik pada suhu $16^{\circ} \mathrm{C}$, kelembapan $97 \%$ serta pH optimum antara 5-7,5.

\section{SIMPULAN}

Berdasarkan hasil penelitian, maka dapat disimpulkan yaitu: 1) Sebanyak 35 spesies teridentifikasi, yang tergolong kedalam 6 ordo, 16 family, dan 24 genus. 2) sebanyak 8 spesies atau 23\% jamur dapat dikonsumsi.

\section{UCAPAN TERIMAKASIH}

Kami mengucapkan terimakasih kepada semua pihak yang telah membantu penyelesaian penelitian ini terutama kepada STKIP PGRI Lubuklinggau, PT Djuanda Sawit Lestari di Kecamatan Muara Kelingi Kabupaten Musi Rawas dan PT Perkebunan Hasil Musi Lestari (PHML) Kecamatan BTS ULU Kabupaten Musi Rawas.

\section{REFERENSI}

Alexopoulus, C.J., \& Benneke, E.S. (1962). Introductory Mycologi. America: Burgess Publishing Company.

Anggraini, K., Khotimah, S., \& Turnip, M. (2015). Jenis-Jenis Jamur Makroskopis Di Hutan Hujan Mas Desa Kawat Kecamatan Tayan Hilir Kabupaten Sanggau. Jurnal Protobiont, 4(3), 60-64.

Arifin, Z. (2006). Kajian Mikoriza Vesikula Arbuskula (MVA) dalam menekan 
perkembangan Penyakit Bercak Ungu (Alternia porri) pada Bawang Putih, (Disertasi). Yogyakarta: Universitas Gadjah Mada.

Arora, D. (1986). Mushrooms Demystified. California: Ten Speed Press.

Badalyan, S.M. (2012). Edible Ectomycorrhizal Mushrooms. Berlin: Springer-Verlag.

Chew, K.S., M. A. Mohidin, M. Z. Ahmad, T. H. N. T. Kamauzaman, \& N. Mohamad. (2008). Early Onset Muscarinic Manifestations after Wild Mushroom Ingestion. International Journal Emergency Medicine, 1(3), 205-208. doi:10.1007/s12245008-0054-y.

Darwis, W., Merisya, Y., \& Supriati, R. (2009). Identifikasi Jamur Tricholomataceae dari Hutan dan Sekitar Pajar Bulan. Jurnal Gradien, 1(1), 1-6.

Darwis, W., Mantovani, A.R., \& Supriati, R. (2011). Determinasi Jamur Lycoperdales yang Terdapat Di Desa Pajar Bulan Kecamatan Semidang Alas Kabupaten Seluma Bengkulu. Jurnal Konservasi Hayati, 07(01), 1-8.

Darwis, W., Desnalianif., \& Supriati, R. (2011). Inventarisasi Jamur yang Dapat Dikonsumsi dan Beracun yang Terdapat di Hutan dan Sekitar Desa Tanjung Kemuning Kaur Bengkulu. Jurnal Konservasi Hayati, 07(02), 1-8.

Gandjar. (2006). Mikrobiologi Terapan dan Dasar. Jakarta: Yayasan Obor Indonesia.

Hasanuddin. (2014). Jenis Jamur Kayu Makroskopis Sebagai Media Pembelajaran Biologi (Studi di TNGL Blangjerango Kabupaten Gayo Lues). Jurnal Biotik, 2(1), 1-76.

Hendritomo, I.H. (2010). Jamur Konsumsi Berkhasiat Obat. Yogyakarta: Lily Publiser.

Hidayati, Hidayat, R.M., \& Asmawati. (2015). Pemanfaatan Serat Tandan Kosong Kelapa Sawit Sebagai Media Pertumbuhan Jamur Tiram Putih. BIOPROPAL INDUSTRI, 6(2), 73-80.

Hiola, F.S. (2011). Keanekaragaman Jamur Basidiomycota di Kawasan Gunung Bawakaraeng (Studi Kasus: Kawasan Sekitar Desa Lembanna Kecamatan Tinggi Moncong Kabupaten Gowa). Jurnal Bionature, 12(2), 93-100.

Jahan, N., Moonmoon, M. A. H. B. U. B. A., \& Shah, M. M. I. (2010). Grower's response to mushroom cultivation technologies disseminated by mushroom development project. Journal of Agriculture \& Social Sciences, 6, 96-100.

Parjimo \& Andoko, A. (2007). Budi Daya Jamur. Jakarta: Agromedia Pustaka.

Proborini, W.M. (2012). Eksplorasi dan Identifikasi Jenis-Jenis Jamur Kelas Basidiomycetes Di Kawasan Bukit Jimbaran Bali. Jurnal Biologi, XVI(2), 45-47.

Tjitrosoepomo, G. (2011). Taksonomi Tumbuhan. Yogyakarta: Gadjah Mada University Press.

Usman, H. (2006). Pengantar Statistik edisi ke-2. Bandung: Bumi Aksara.

Utoyo, N. (2010). Bertanam Jamur Kuping di Lahan Sempit. Jakarta: Agromedia Pustaka.

Wilkinson, J. \& Buczacki, S. (1982). Mushrooms \& Toadstools. London: Collins. 